\title{
Linguistic Landscape Westernization and Glocalization: the case of Kazan, Republic of Tatarstan
}

\section{[Вестернизация и глокализация лингвистического ландшафта г. Казани, Республика Татарстан]}

\author{
Marina I. Solnyshkina - Aliya R. Ismagilova
}

\section{DOI: 10.18355/XL.2015.08.02.36-53}

\begin{abstract}
Аннотация
В статье описаны процессы ускорения динамики изменения лингвистического ландшафта г. Казани, столице Республики Татарстан, выявлены роль и место государственных (русского и татарского) и западноевропейских языков в формировании структуры и состава изучаемого феномена. Своеобразие ситуации в Татарстане состоит в том, что лингвистический ландшафт республики, базирующийся на русском (славянский, флективный) и татарском (тюркский, агглютинативный), вобрал в себя многочисленные заимствования из западных (английского, немецкого, французского, испанского и ряда других) языков. Модернизация современного казанского лингвистического ландшафта состоит в его вестернизации: охраняемые законом государственные вывески на русском и татарском языках находятся в окружении рекламы, текст которой в большинстве случаев содержит вкрапление на одном из западноевропейских языков или транслитерированный текст. Глокализация казанского лингвистического ландшафта проявляется в усилении этнических (преимущетвенно татарских) традиций и использовании языка как средстве отстаивания национальных и этнических интересов.

Ключевые слова

вестернизация, глокализация, лингвистический ландшафт, эргоним, языковая политика, глобализация
\end{abstract}

«Если ваш язык обречен на умирание, то не потому, что его смерть неизбежна, а потому, что у вас не хватает мудрости и решительности сохранить его» (Донал О'Ригэн)

\section{Введение}

На территории Республики Татарстан ${ }^{1}$ (далее РТ) как на государственном, так и на бытовом уровнях, взаимодополняя и взаимообогащая друг друга, в течение длительного времени сосуществуют татарский и русский языки. Русский язык Татарстана имеет ряд заимствований из татарского, не функционирующих на территории других регионов России (Galiullin, 1998: 108-

\footnotetext{
${ }^{1}$ Татарстан является одной из самых многонациональных территорий России представители свыше 115 национальностей проживают на территории республики, в том числе 8 национальностей, численность населения которых превышала 10 тысяч человек: татары, русские, чуваши, удмурты, украинцы, мордва, марийцы и башкиры. Татары являются одним из крупных тюркоязычных этносов. Общая численность 6.648,7 тыс. чел. (1989). Традиционная религия татар - ислам суннитского толка, за исключением небольшой группы христиан-кряшен, которые были обращены в православие в XVI-XVIII вв.
} 
114). В татарском языке заимствования из русского многочисленны и разноплановы (Smolyakova, 1982: 74-81). Уникальность современной ситуации в Татарстане состоит в том, что огосударствление татарского языка совпало по времени с изменениями в экономической ситуации республике, когда на рынке товаров и услуг появились новые продукты, а в лингвистическом ландшафте новые явления. Такое положение не ограничило сферы употребления русского и татарского языков, но расширило и обогатило последние.

Модернизация лингвистического ландшафта РТ осуществляется в двух основных не противоречащих друг другу направлениях: вестернизация и глокализация. Вестернизация как процесс привнесения (экспансии) западноевропейских ценностей и стереотипов наблюдаема повсеместно: не только в речь, но и в язык проникают слова, либо дублирующие исконные, либо привносящие новые, как правило, чуждые коренному населению концепты. Многочисленные иностранные заимствования в лингвистическом ландшафте Казани - хорошая база для ряда таких явлений как калькирование, транслитерация, контаминации исконных наименований, за которыми нередко следует вымывание принципов традиционных этнокультурных и национальных ценностей общества. Глокализация реализуется не только в стремлении сохранить, но и открыть этническую (преимущественно татарскую) самобытность внешнему миру. Аналитизм татарского языка позволяет инкорпорировать татарские вкрапления в тексты русских и иностранных (преимущественно английских) вывесок, сообщающие всему тексту положительную для коренного населения коннотацию и яркое звучание.

\section{Теоретическая база исследования: состояние изученности проблемы}

Изучением коммуникации людей в жизненном пространстве города и социокультурной экологии городов занимались многие зарубежные ученые. Среди них особая роль принадлежит работам А. Шюц, Дж. Голда, С. Милгреда, М. Вебера и др. Как указывает Дэвид Фрисби, понимание города как текста, «потенциально расшифровываемой констелляции знаков и символов», было в различных формах распространено в литературе и критике начиная «по крайней мере с девятнадцатого века» (Frisby, 2002). За последние годы в отечественной лингвистике появилось значительное количество работ, посвященных лингвистическому ландшафту отдельных городов и регионов (И.А. Астафьева, А.В. Беспалова, М.В. Голомидова, Л.В. Грибанова, С.В. Земскова, Р.И. Козлов, И.В. Крюкова, М.Я. Крючкова, А.М. Мезенко, М.Е. Новичихина, Е.А. Трифонова, Н.В. Шимкевич, А.Г. Широков, Д.А. Яловец-Коновалова). Отдельные аспекты татарстанской эргонимии рассмотрены в работах И.М. Низамова, Г.Р. Галиуллиной, О.Р. Хисамова и др. Однако проблемы эклектики современного лингвистического ландшафта г. Казани не изучены.

Под лингвистическим ландшафтом (далее ЛЛ) авторы представленной работы понимают систему письменных знаков, используемых в общественной сфере (публичном пространстве) городской среды (Backhaus, 2007) и выполняющих две основные функции: информативную и символическую. Степень и плотность присутствия конкретного языка в ЛЛ всегда есть показатель значимости, силы, релевантности языка в социуме. Именно он дает представление и делает социополитический дискурс осязаемым. Современные исследователи признают, что именно лингвистический ландшафт дает яркое представление о реально существующих в умах населения идеях многоязычия (Shohamy, 2009: 110). Он символичен и может служить определенным индикатором настроений отдельных групп, общества и регионов.

Английский язык, используемый в настоящее время повсеместно, есть своеобразный символ глобализации, определяемой авторами как процесс 
усиливающейся интеграции экономик и обществ во всем мире. Широкомасштабное использование английского языка в неанглоязычных странах вызывает опасения относительно национальной и этнической идентичности, статуса и роли национальных и этнических языков в мультилингвальных контекстах (Pennycook, 1994; Philipson, 2003; Shelestyuk, 2012; Karabulatova, 2013).

В качестве одного из основных компонентов лингвистический ландшафт города содержит эргономикон - собственные имена предприятий различного функционального профиля: делового объединения людей (научных, учебных, производственных учреждений), коммерческих предприятий (агентств, банков, магазинов, фирм), объектов культуры (кинотеатров, клубов, развлекательных учреждений, театров, парков), спортивных заведений (комплексов, стадионов), представляющие собой единицы лингвистического пространства города (Emelyanova, 2007). Известно, что эргонимикон, решая задачи сообщения и воздействия, выполняет в языке ряд функций, основными из которых являются: 1) номинативно-выделительная; 2) информативная; 3) рекламная; 4) мемориальная; 5) эстетическая; 6) функция охраны собственности. Эргонимы, как и вся наружная реклама, имеют высокую повторяемость контактов, именно поэтому их эффективность и степень воздействия на языковую личность являются крайне важными. Система эргонимов - фундаментальный фактор, структурирующий городское пространство в сознании языковой личности горожанина. Восприятие и оценка эргонима носителем языка осуществляется по некоторому целостному образу мыслеречевой ситуации. Анализ эффективности эргонимического названия позволяет сделать вывод о том, что последнее должно характеризоваться коммуникативной эффективностью, которая зависит от: 1) информативности названия; 2) ассоциативного соответствия; 3) фоносемантической привлекательности; 4) степени его соответствия картине мира и ценностных ориентиров языковой личности, на которую оно нацелено (Emelyanova, 2007).

Суть вестернизации в самом широком понимании термина мы рассматриваем как заимствование западноевропейских (преимущественно англо-американских) стандартов в различных областях: политике, экономике, образовании и культуре. В области языка «вестернизация» предполагает изменения в письменности, перестройку традиционных форм вежливости, развитие системы лексических единиц, взаимопереводимых по отношению к «престижным» (западноевропейским) языкам (Шелестюк, 2013). При этом «вестернизация» умышленно преподносится как неизбежный и логический процесс развития и модернизации языков в развивающихся странах, исключающий возможность их эволюции независимо от западноевропейских языков (Shveytcer, 1977).

Под термином глокализация, введенным в оборот Р. Робертсоном, понимаем способы переплетения глобального с локальным (Robertson, 1992). Процесс глокализации реализуется, в частности, в адаптации глобального продукта к локальному потребителю. Глобализация бренда, например, идет одновременно с процессом его локализации (Avdokuskyn, 2008). Исследователи считают, что в ситуации постмодерна начинается взаимная адаптация традиционных локальностей и универсалистских тенденций и более того осознание взаимозависимости и взаимообусловленности. Локальные культуры осознают, что они могут сохраниться и развиваться, лишь играя свою особую роль в глобальном пространстве - изоляционизм их погубит (Shtepa, 2004). Глокализация и глобализация ярко отражены в эргономиконе Казани. 


\section{Материал и методы исследования}

Представленные результаты анализа лингвистического ландшафта г. Казани базируются на собственной картотеке авторов - фотографиях 795 текстов письменных знаков общественной сферы: из них 478 текстов вывесок и 317 рекламных щитов государственных органов, общественных организаций и коммерческих предприятий г. Казани, сделанных в период с сентября 2009 по май 2014 г. Фотографирование осуществлялось в центре города Казани (ул. Баумана, Татарстан, Пушкина, площадь Тукая и др.), основных местах скопления туристов и горожан - железнодорожных вокзалах, автостанциях, аэропорте, исторической части города (Кремль, Татарская слобода), промышленных районах (Заречье, Оргсинтез, Промбаза), спальных микрорайонах (Азино, Горки, Квартал). Для контрастивного анализа в качестве источника знаков наружной рекламы советского периода (97 единиц) привлекались Интернет ресурсы.

Исследование включало три этапа: на первом этапе - при сборе и систематизации знаков - был использован описательный метод, в рамках второго этапа были осуществлены словообразовательный анализ и семантический анализ собранных знаков, количественный анализ и интерпретационный метод применялись на третьем этапе исследования при определении наиболее распространённых языков, знаков и их типов.

\section{Татарский язык: современное положение}

Татарский язык прошел классический путь от языка традиционной аграрной общины (в 1897 г. 91,5\% татар составляли сельчане) через язык культурного меньшинства в условиях советской индустриализации до титульного, одного из двух государственных языков в современном Татарстане.

Книгоиздание на татарском языке начато в конце XVIII в. К началу XX вв. (по другим источникам к середине XIX вв.) сложился литературный татарский язык, развиваемый широким спектром государственных и общественных сфер: СМИ, образование, театр, научные учреждения, издательства и т.д. До 1927 года татарский алфавит имел арабскую основу, затем был введен "яналиф" ("новая азбука"), использовавший латинскую графику, а в 1939-м году графической основой татарской письменности стала кириллица.

До недавнего времени в республике действовала Государственная программа Республики Татарстан (далее РТ) по сохранению, изучению и развитию государственных языков (русского и татарского) Республики Татарстан и других языков в Республике Татарстан на 2004-2013 годы (Государственная программа, 2004). Целью данной программы являлось, в том числе, обеспечение функционирования татарского языка как государственного языка Республики Татарстан, сохранение, изучение и развитие татарского языка как основы национальной культуры, полноценного средства общения и консолидации татарского народа. Государственная программа 2004г. определяет различные направления деятельности, конкретизирует мероприятия, порядок и сроки исполнения, их финансовое, кадровое и научно-исследовательское обеспечение. Благодаря Программе значительно расширились функции татарского языка в различных государственных институтах: в сфере образования, судебно-правовой системе, финансах и банках, спорте, культуре и др.

Однако, не смотря на огромное количество мероприятий, нацеленных на расширении функций татарского языка, он значительно уступает русскому языку. Такого рода положение дел приводит к довольно типичной ситуации: вместо трансформации в ходе использования и передачи из поколения в 
поколение, язык употребляется все меньше и меньше. В подобных случаях "поток" общения и передачи "иссякает", поскольку носители, добровольно или вынужденно, переходят на другой, преобладающий в данном обществе, более престижный и могущественный язык, и перестают учить детей родному языку или языкам (Maffi, 2003).

Социологические опросы в современном Татарстане свидетельствуют о первостепенной роли языка среди факторов этнической идентификации. В исследовании социокультурных проблем молодежи нефтяных районов республики (Бугульма, Азнакаево, Мамадыш) Гарипов Я.3. предпринял попытку оценить значимость родного языка в молодежной среде (Garipov, 2002; Garipov-Solnyshkina, 2006). Индекс значимости родного языка (средняя взвешенная) для татар оказался равен $21 \%$, для русских - 17,9\%; различие практически несущественное. Довольно низкое значение индекса для русской молодежи Татарстана можно вполне объяснить функциональной развитостью русского языка во всех сферах жизнедеятельности и отсутствием скольконибудь заметных проблем с его применением в будущем. В то же время невысокое значение индекса для татарской молодежи свидетельствует об отсутствии у нее адекватного понимания, осознания важности и значимости языка, серьезности ситуации с этнически родным языком, проблем его функционального развития.

Современный Татарстан, как и вся Россия, находится в состоянии преодоления последствий перехода от советской эпохи к демократическому транзиту и от переходного времени к выбору своего пути и места в мировом сообществе. Выбор идет по трем векторам - политическому, экономическому, с соответствующими последствиями в социальной структуре, и идеологическому, в соответствии с которым выстраивается пространство меняющихся идентичностей и солидарностей, их ценностно-нормативный и коммуникационный потенциал. В современных условиях фиксируются две разнонаправленные тенденции - глобализационная и историческая, социальнокультурная. Первая реализована в распространении единой системы информации, интернет-сетей, единых трудовых норм, соответствующих перетеканию капитала, и одновременно относительно низкой пространственной мобильности обедневшего российского населения в условиях колоссальных размеров страны и региональных административных границ, замыкающих жизнедеятельность проживающего на их территории населения. Вторая историческая, социально-культурная традиция - обуславливает глокализацию как в масштабах страны, так и ее регионов (Drobidzeva, 2003).

\section{Лингвистическое пространство г. Казани}

Казань - город с тысячелетней историей, многовековой и современной архитектурой, миллионным населением, надземным и подземным общественным транспортом и широкой сетью автострад - предоставляет горожанам широкий спектр допущенных Управлением наружной рекламы и информации г. Казани к размещению конструкций с текстом: вывески, биллборды, рекламные щиты, афиши, пилон, пиларсы, ситиборды, еврощиты, медиафасады, брандмауэры и др.

Наружная реклама всегда занимала одну из ведущих позиций в столице Татарстана. В советский период нашей истории имела место устойчивая регламентированность эргономии и рекламной коммуникации (Gorodov, 2006). В настоящее время в соответствии с законодательством РТ все государственные учреждения республики имеют вывески, выполненные на татарском и русском языках: «Тексты документов (бланков, печатей, штампов, 
штемпелей) и вывесок с наименованиями органов государственной власти, органов местного самоуправления, государственных органов, предприятий, учреждений и иных организаций оформляются на государственных языках Республики Татарстан» (Zakon, 2004). Согласно Постановлению Кабинета Министров РТ № 614 «Об очередных мерах по реализации Закона Республики Татарстан «О языках народов Республики Татарстан»», принятому 5 августа 1997 года, «<..>наименования географическим объектам присваиваются на государственных языках Республики Татарстан и не подлежат переводу. При утверждении названия географического объекта должны быть указаны нормативные формы его написания на обоих государственных языках Республики Татарстан в соответствии с правилами и традициями употребления в языках географических названий».

17 декабря 2001 года на заседании Комиссии по реализации языковой политики в наглядно-информационной атрибутике и Комиссии по топонимике Общественного совета по реализации закона Республики Татарстан «О языках народов Республики Татарстан» при администрации г.Казани был утвержден справочник «Наименования улиц города Казани», регламентирующий написание улиц и других составных частей города на татарском и русском языках и призванный служить основой для наименования остановочных площадок общественного транспорта и дорожных указателей в Республике Татарстан. Данный документ обязывает все без исключения государственные и частные компании и организации размещать информационные и рекламные табло на двух языках. Например, Казанский (Приволжский) федеральный университет - тат. Казан (Идел буе) федераль университеты, Министерство лесного хозяйтсва РТ - mam. Татарстан Республикасының Урман хужалыгы министрлыгы, Национальный музей РT - mam. Татарстан Республикасы Милли Музее, Национальная библиотека РT mam. Татарстан Республикасы Милли китапханәсе.

Для правильного написания названий улиц на татарском языке определена схема образования наименований, которую составляют пять групп. В первую группу входят наименования улиц, содержащие имена и фамилии. Например, улица Абая Кунанбаева - Абай Кунанбаев урамы, улица Луковского - Луковский урамы, улица Салиха Сайдашева - Салих Сәйдәшев урамы и др. Улица Волгоградская - Волгоград урамы, улица Енисейская Енисей урамы, улица Югославская - Югославия урамы, улица Краснодонская - Краснодон урамы относятся ко 2-й группе: «наименования улиц, образованные от названий географических объектов (названия стран, республик, городов, районов, поселков, рек, озер и т.п.)». К третьей группе были отнесены наименования улиц, корни или основы которых совпадают в татарском и русском языках. Например, улица Астрономическая - Астрономия урамы, улица Новаторов - Новаторлар урамы, улица Шоссейная - Шоссе урамы и др. Улица Балачак - Балачак урамы (тат.детство), улица Васильковая - Васильковая урамы, улица Горсоветская - Горсоветская урамы, улица Ударная - Ударная урамы, улица Чишмяле - Чишмәле урам, улица Яшел Яшел урам относятся к 4-й группе: «наименования улиц, состоящие из слов, не приводимых в соответствие с нормами правописания и произношения другого государственного языка, и оформляются согласно правилам транскрипции». Проспект Победы - Жиңү проспекты и площадь Свободы - Ирек мәйданы, улица 40 лет Победы - Жиңүнең 40 еллыгы урамы, улица Задне-Хади Такташа - Аргы һади Такташ урамы относятся к 5-й группе: «наименования, традиционно употребляемые и на татарском и на русском языках, при этом не приводящие к затруднению при определении их местонахождения» (Ahmadiev, 2001). Постановление Исполнительного комитета г.Казани от 07.02.2014 №600 
сохранило указанные группы наименований и представило полный список наименований улиц г. Казани специальным реестром (www.uag.kzn.ru).

Управление наружной рекламы и информации г. Казани разработало ряд документов, нацеленных на упорядочивание эргономикона и рекламы г. Казани. Нормативные акты в области наружной рекламы и информации данного государственного органа, в частности, содержат указания относительно использования государственных языков в текстах вывесок. Наименование организации, зарегистрированные товарные знаки, знаки обслуживания должны быть представлены потребителям в оригинальном виде на том языке, на котором они зарегистрированы. Режим работы, место нахождения (адрес), профиль деятельности организации доводится до потребителей на обоих государственных языках Республики Татарстан. К профилю деятельности относятся следующие понятия: «магазин» (в т.ч. виды товаров - «продукты», «книги», «промтовары» и т.д.), «столовая», «парикмахерская», «аптека», «юридические услуги», «вокзал», «стоматология», «салон красоты» и т.п. Допускается размещать только на одном из двух государственных языков Республики Татарстан без перевода на другой имена собственные или названия. Например, в вывеске «магазин Сияние» обязательным является перевод на татарский язык только слова «магазин», так как это профиль организации. Перевод названия «Сияние» не требуется. Аналогично, в вывеске «Керпе Кибете» требуется перевод на русский язык слова «кибете» (тат. магазин), так как это профиль организации. Перевод названия «Керпе» не обязателен. Перевод не явлется обязательным, если в вывеске присутствует художественный или дизайнерский замысел автора, который будет искажен при переводе (Gosudarstveniye, 2012). Однако данное правило не распространяется на иностранные бренды: использование в текстах вывесок иностранных языков допускается при наличии перевода на государственные языки Республики Татарстан. Например, вывески магазинов электроники «DOMO», спутниковых антенн «Crosna», радиоэлектроники «Ortex» должны содержать перевод (или транслитерацию/транскрипцию) на русский и/или татарский языки. В случаях использования двух и более языков тексты должны быть идентичными по содержанию и техническому оформлению, выполнены грамотно и разборчиво.

В связи с проведением летом 2013 года Всемирной летней Универсиады (Universiade KAZAN 2013 Russia) Управление наружной рекламы рекомендовало учреждениям, организациям и компаниям, находящихся в непосредственной близости спортивных и туристических маршрутов, дополнительно к государственным языкам Республики Татарстан предоставлять информацию о режиме работы, месте нахождения (адрес), профиле деятельности объектов (спортивных сооружений, транспортных узлов, гостиниц, ресторанов, театров, музеев, выставок, крупных торгово-развлекательных центров) на английском языке. Например, ул. Воровского - Воровский ур. Vorovskiy Str., ул. Восстания - Восстания ур. - Vosstaniya Str., улица Пушкина - Пушкин ур. - Pushkin str., Бауман ур. - ул. Баумана - Bauman str., Выход на посадку - Самолетка чыгү урыны - Departure Gate, Ювелирный салон FREY WILLE, режим работы: понедельник - воскресенье 10.00 - 22.00. эш вакыты: дүшәмбе - якшәмбе 10.00 - 22.00. OPENING HOURS Mo - Su 10:00am 10:00pm.

В январе 2013 года количество рекламных поверхностей в городе, по данным Управления наружной рекламы и информации г. Казани, превышало 2 000 штук, а их общая площадь составила 50000 кв.м. Осенью 2013 г. была внедрена новая территориальная схема размещения рекламных конструкций, согласно которой общее число коммерческих щитов в городе значительно 
сократилось. В историческом центре города были полностью демонтированы билборды, убраны перетяжки, размещенные над проезжей частью улиц. В настоящее время меняется порядок размещения рекламы на зданиях. В 2013 году власти Казани ввели запрет на размещение рекламы на бортах автобусов, трамваев и троллейбусов. Очевидно, что эта мера будет способствовать переходу с рекламы на общественном транспорте на современные электронные табло и бегущие строки. Государственные органы осуществляют жесткий контроль за выполнением закона: в феврале 2014 г. компания "Ривиера" оплатила назначенный республиканским Управлением федеральной антимонопольной службы штраф за непереведенные на русский язык рекламные вывески Sale в витринах магазина.

\section{Эргономикон г. Казани: словообразовательный и семантический и анализ}

Эргономикон Казани - полиэтничного города, культурного, экономического, научного и спортивного центра - демонстрирует, с одной стороны, крепкие межкультурные связи русского и тюркоязычного населения города, a, с другой стороны, Республики Татарстан - с западными и восточными странами.

Объем и степень представленности языка(ов) в текстах государственного, общественного или коммерческого знака суть отражение статуса и экономической силы соответствующих этносов. Наиболее многочисленными в лингвистическом ландшафте города являются наименования объектов на русском языке: Светлана, Марина. Швея, Умелец, Любимые цветы, Садовник, Восьмерка, Пять кружек и др. Типичной чертой казанского ландшафта являеются вывески на татарском языке: мечеть АльМарджани, мечеть Иске - Таш, магазин, Ильдан, кафе Флера, гостинииа Булак, бильярдный клуб Зилант, кафе Алия. Русско-татарский билингвизм большинства населения города обусловливает наличие и понимание профиля «безыменных» городских объектов уровня микрорайона города на татарском языке: Даруханэ, аптека, Икмэк, хлеб, Ашамлыклар, продукты, Китапханэ, библиотека, Тылсым, ателье и др. Зафиксирована тенденция к использованию русского термина в качестве индивидуального собственного имени: Столовая, Кафе, Кафе-бар, Кафе-караоке, Кофейня, Кафе-мороженое, Кафетерий, Спорт-бар, Торговые ряды, Аптека, Цирюльня, Трактир, Трактиръ, Парикмахерская, Парикмахерский салон.

Как на центральных, так и периферийных улицах города многочисленны названия, содержащие иноязычные заимствования: Мулен Руш, кафе, Спорт Мастер, магазин, Дисконт Центр, Баттерфляй, кафе, Эльдорадо, магазин, Diamond Rose, флористический салон, Diva, цветочный салон, Elitaflora, иветочный магазин, Pink Rose, иветочный магазин. Выявлены немногочисленные для города с миллионным населением - около 60 единиц эргонимы-названия спортивных объектов и объектов общепита, источником названий которых послужили японский и китайский языки: Окинава, каратэклуб, суши-бар, Киокусинкай, спортивньии клуб, Куоtо, суши-бар Киото, Small Tokyo, суши-бар, Yahhoo, ресторан, Акинава, суши-бар, Акэбоно, ресторан суши, Банзай, автосуши, Ва-би Са-би, суши-бар, Гин-Нотаки, ресторан.

Наиболее типичными тематическими источниками наименований современных эргонимов в г. Казани являются (в порядке убывания): 1) артефакты (Мотор, спортивная школа, Факел, центр детского технического творчества, Парус, яхтклуб); 2) имена и прозвища лиц (Лотрэк, бильярдный клуб, Алмаз, магазин, Катерина, магазин, Ева, ателье); 3) имена топонимической семантики (Лебяжье, ресторан, Альбион, бильярдный клуб); 4) имена литературно-мифологических образов (Рубаи, ресторан, Стрелковый 
клуб "Робин Гуд", Парнас, ООО, оптовая фирма, Барон, бильярдный клуб,); 5) названия объектов и явлений природы (Торнадо, бильярдный клуб, Тюльпан, учебно-спортивный центр, Фиалка, бар-ресторан, магазин, Бамбук, сушибар), 6) космонимы: Кояш (тат. Солнще), досуговый иентр, Венера, туристическое агентство, Сатурн, спортивный комплекс); 7) слова, содержащие сему “время": Март, медииинский иентр, кафе, Заман, Кич, Яз, магазин строительных материалов, Май, парикмахерская и ряд др. Как правило, номинаторы предпочитают использовать готовые единицы языка, апеллируя к "мысленному досье" реципиента, перенося обозначения уже существующих и известных понятий и реалий на названия своих предприятий и компаний.

Словообразовательный анализ эргономикона г. Казани осложнен присутствием двух языковых систем: татарской и русской, однако в обеих выделяются семантический тип и морфемная деривация.

Семантический способ наиболее распространён и реализуется в метонимической онимизации (стоматологическая клиника Ак теш, организация, занимающаяся укладкой дорожных плиток Ак таш, агентство Юрист, магазины Бакчачы, Ветеран,) и метафорической онимизации (магазин газового оборудования Ялкын (тат. пламя) издательство Рухият (тат. духовность) (Amirova, 2011).

Морфемная деривация объективирована в аффиксации (магазин Гастрономчик), усечениях (магазин кондиционеров Конди, трикотажное ателье Трикота, салон штор Элегант), аббревиацией (сеть салонов МТС, магазин Н\&M, «IQ», кафе KFC ), словосложении (клиника Евродент, Евромед, магазин Техносила, инвестиционная компания Элемтә-инвест, кафе Алан-аш, студия Нур-медиа), субстантивации (прилагательных (сеть торговых супермаркетов Бәхетле, кондитерская фабрика Тәмле, продуктовый магазин Снежный, Татлы, видеостудия Бай) и наречий (дизайн-студия Алга, кафе Югарыда).

Многообразны приемы языковой игры: контаминация (магазин Спортугалия (спорт + Португалия)), гендиадис (кафе Гуси-лебеди, Киш-миш), гибридизация (магазин Xoposhow), капитализация (пивбар ВEЕRлога), паронимия (сеть кафе Жар-пицца). Высокочастотны эргонимы, образованные трансонимизацией: кафе Хоттабыч, Чиполлино, Аэлита.

Вестернизация лингвистического ландшафта: специфика г. Казани. Вестернизации, как уже указывалось, предполагает полную или частичную переориентацию общества, не принадлежащего к западнохристианской культурной традиции, на социокультурное развитие по образцу развитых стран Запада и/или заимствование элементов западной культуры, начинающих играть значимую роль в социокультурных процессах общества-реципиента. При этом данные процессы осуществляются внешне ненасильственно, но добровольно, при поддержке государства и элиты государства-рецепиента. Вестернизация влечет за собой изменения в письме, перестройку традиционных форм вежливости, заимствование не только лексических единиц из западноевропейских языков (в настоящее время преимущественно из английского) (Shelestyuk, 2013), но и соответствующих концептов. Рассмотрим каждую из трех составляющих на примере современного лингвистического ландшафта г. Казани.

Рецептивный (воспринимающий) билингвизм большого числа населения г. Казани сделал возможным появление в лингвистическом ландшафте большого слоя заимствованной лексики. Лингвистический ландшафт г. Казани демонстрирует два основных способа использования 
иностранных слов: переключение кодов и транслитерацию. При переключении кодов в текст вывески на государственных языках РТ вкрапляется текст ${ }^{1}$ на иностранном языке: Ultra $\mathbf{R e D}^{2}$, Казань, Праздничное агентство Fantasy Day, АГЕНТСТВО Rusart wedding, АГЕНТСТВО Festival d'lux, Праздничное агентство wedding-vip, Fest-event, Freaky Mouse, Fox group (Фокс груп), Априори PR АГЕНТСТВО, "Hes Group" (Хес груп) ПРАЗДНИЧНОЕ АГЕНТСТВО, VIp зона, АКВАПАРК РИВЬЕРА. ВСЕ ВКЛЮЧЕНО. ГОРКИ, БАССЕЙНЫ, SPA-КОМПЛЕКС, Event. Агентство "Праздничный рай".

«Островное» переключение кодов менее характерно для ландшафта г.

Казани: МАХІмально выгодные иены; Жемчужина эVOLVOлючии (автомобиль VOLVO).

Транслитерация заимствованных слов как побуквенная передача текстов и отдельных слов одной графической системы (преимущественно латиницы) средствами другой графической системы (кириллицы), создает основу для «взаимопереводимого» корпуса слов: Квестория, Агентство Торжеств Дабл Ю, Концертное агентство «Смайл», Миссис Хадсон, Агентство фея Винкс, MarSaLe (Марсаль).

Казанский лингвистический ландшафт демонстрирует вестернизацию слоганов и наружной рекламы всех современных институциональных дискурсов (сервиса, спорта, образования, здравоохранения, судебно-правовой системы и др.) в различных формах и проявлениях: заимствования, изменения в орфографии, когезии и когерентности дискурса, коммуникативных стратегиях. Особо высокочастотны в слоганах заимствования: Вплоть до сезона 2009 года на автодроме проводились заезды любителей, дрифт-сессии и тест-драйвы. Дизайнерский конкурс от KazanRing! Lada Junior - новый этап, новые участники. Живые квесты в нашем городе, Отдадим Suzиki в добрые руки! Toyota Camry. Первоклассный бизнес-класс. Keеp calm and Love Tatarstan (англ. Успокойтесь и любите Татарстан) (на фоне татарстанского флага).

Практика использования инициальных прописных букв в названиях организаций и месяцев, соответствующая нормам английского правописания, постепенно становится повсеместной в названиях городских объектов: Искусство Праздника, Мастер Церемоний, Русский Ситец, Радуга Позитива, Ярмарка Желаний, Индустрия Событий, Маэстро Церемоний, Мастер Шоу, LiveTiming RHHCC 18-19 Июля, Концертное Агентство SMILE, Фантазия Детства, Агентство праздников Веселый День, Лаборатория Праздника.

Изменения в написании русских слов, как правило, продиктованы такими прагматическими целями как привлечение внимания пользователя, формирование имиджа рекламодателя, экономия языковых средств: ТурБюро ЧЕРЕПАХА, КреАген, Самое_Самое. В стремлении следовать оригиналу и сохранить все смысловые оттенки современный рекламодатель может допускать

${ }^{1}$ Среди внутрифразовых переключений выделяем вкрапления и островные кодовые переключения. Вкрапления представляют собой одиночные лексические единицы гостевого языка - морфемы или слова, которые подчиняются грамматическим правилам матричного языка. Островные переключения состоят из одной или нескольких лексических единиц гостевого языка и сопровождающих их системных морфем гостевого языка (Isaeva, 2010). 2 Здесь и далее сохраняется орфография и пунктуация вывесок г. Казани, зафиксированных картотекой фотографий авторов статьи. 
в переведенном тексте наружной рекламы субстандартные формы и намеренные ошибки WASSSSSUP?! / Кагдилаааааa?! (реклама пива Budweiser), It Gives You Wiiings/ Red Bull окрыляяееет (реклама Red Bull), Hungry? Grab a Snickers / Проголодался? Сникерсни! АББАсолютно солнечный мюзикл! They're grrreat! / Они охрррененные! (реклама Kellogs).

Смена ценностных стереотипов наблюдаема в отрицательно окрашенных номинациях городских объектов. Лингвистический ландшафт Казани пестрит ассоциативно-образными пейоративно окрашенными наименованиями: кафе Обжорный ряд, бар MadHouse (англ. сумасшедший дом), кафе Три толстяка, бар Дикий Койот, Детские праздники в научном стиле СумаСшедшая наука, кафе Остап Бендер, центр релаксации Мумия.

Независимо от способа номинации любое название как свернутый текст является средством общения номинатора и адресата, с помощью которого осуществляется передача определенной информации адресату-потенциальному потребителю товаров или услуг компании. Группа наименований и слоганов, содержащих в своем значении сему 'экономность' - Бережная аптека, СП ВМЕСТЕ ДЕШЕВЛЕ, Плати меньше (ЦентрОбувь) - свидетельствует о появлении слоя населения с низкими доходами, признающего свое невысокое положение в обществе. В доперестроечные времена подобного рода ситуацию трудно было бы представить.

Расслоение общества косвенно отражено и в наименованиях компаний и предприятий, семантика которых содержит семы 'богатсво', 'стиль', ‘гламур', ‘красота', ‘простота', 'легкость', ‘беззаботность', ‘удовольствия': ювелирный салон Caprice, ресторан Гурман, агентство Вишня в шоколаде, Студия эксклюзивных развлечений, магазины Rich (англ. богатый), "Аполлон Трэвел", г. Казань, Детское праздничное агентство Magics, Все для тебя, "Мастерская женского счастья", торговый центр Гранд Плаза, Бутик соблазна "Штучки", Агентство Праздничный рай, Ярмарка Желаний, Империя Развлечений, Страна Чудес, Time for Surprise, Праздник? Праздник. Праздник!, магазины Лакомка, Рremium Агентство Праздника, Фабрика праздников, Делаем Шоу Творческая группа.

Усваивая названия предметов и систему социальных связей, человек с детства обретает национальную и этническую идентичность. Перколутивный эффект слоганов советской эпохи был нацелен на аксиологическую цепочки: «труд - вознаграждение - отдых» (В сберкассе деньги накопила, путевку на курорт купила), «государственное - лучшее» (Трехгорное пиво. Выгонит ханжу и самогон Казсельпром), «служить государству - долг и честь» (Что ты сделал для Родины?). Современный лингвистический ландшафт города пропагандирует ряд чуждых русской национальной культуре концептов: «отсутствие ограничений на развлечения»- Все в твоей власти (сигареты Esse Lights), Ночь твоя - добавь огня! (сигареты Pall Mall), «доступность алкогольных напитков для молодежи» - Кто идет за Клинским? Время с Толстяком летит незаметно! (реклама пива), «ирония в отношении истории государства» - Ночь. Party. Partyзаны (сигареты Pall Mall), «неуважение к женщине»- Женская сущность (реклама сигарет Pine), «продаваемость всего» - Купи это. Продай это. Люби это (реклама ЕВау).

Высок эффект воздействия слоганов, заимствованных вместе с импортируемыми товарами и содержащих ценностные установки в императивах: Бери от жизни все (Pepsi). Alpen Gold - не пытайся устоять! Сделай паузу скушай Twix. Аксиологическая диада «продукт - удовольствие», реализуемая в утверждениях, нацелена на аналогичный перлокутивных эффект - «купи/стань одним из пользователей, чтобы насладиться/стать богаче/ добиться успеха/ 
выздороветь»: Есть перерыв, есть Кит-кат! (Kit-Kat). "Эдельвейс" - пиво, доставляющее удовольствие. Лексус. Прикосновение к роскоши (автомобили Lexus). Татфондбанк - технология успеха.

Изменение форм вежливости наблюдаемо в рекламных слоганах автомобилей, где при прямой апелляции к потребителю, как правило, взрослому мужчине с высоким социальным статусом, используется обращение на «ты», предполагающее более доверительные отношения, но не типичное для русской или татарской этнокультур в отношениях «покупатель - продавец: Открой для себя_ , Попробуй__. Не отказывай себе в приключениях. Mazda. Заведи идеал! Тебе водить! (Игра начинается.) Компания: VOLKSWAGEN. Как правило, это выбор компании при переводе соответствующих слоганов с английского языка: Grab life by the horns/Возьми жизнь за рога (реклама компании Dodge), Envy yourself/Позавидуй себе, Live your passion/ Живи со страстью, Love what you buy/ Люби то, что покупаешь, Кеер Walking/Продолжай движение, For the new уоu/Для нового тебя (товары компании BEKO), Fly with US / Летай с нами (игра слов, us -c нами, US США).

Показательно, что лексический корпус рассматриваемого лингвистического ландшафта содержит большой процент взаимопереводимых на западноевропейские языки единиц - лексем, имеющих в свое семантике аналогичные семантические элементы и не несущих этнически маркированные компоненты. Основу корпуса составляют товарные знаки и наименования продуктов всемирного рынка (айпад - iPad, айфон - iPhone, Форд - Ford, Феррари - Ferrari, Шкода Skoda, Крайслер - Chrysler, Опель - Opel, Шевроле - Chevrolet, кока-кола coco-cola, пепси - pepsi, гель - gel, кондиционер - conditioner, скраб - scrub, спрей - spray, бгамбургер - hamburger, фаст-фуд - fast food, чикен бургер chicken burger, чипсы - chips), а также услуги и действия (пилинг - peeling, лифтинг - lifting, отокс - botox, мезотерапия - mesotherapy, солярий solarium, спа - spa, эпиляция - epilation, релаксация - relaxation, шоппинг shopping).

Аналогичная форма слов этого слоя в западноевропейских, русском и татарском языках лексики не означает невозможности развития различий в их семантике, форме и функциях.

\section{Глокализация лингвистического ландшафта: специфика г. Казани}

Глокализация как культурная реакция на вестернизацию характеризуется обострением интереса к самобытным локальным отличиям и нацелена на их сохранение и усиление. При этом глокализация не означает стремления к реставрации прежних местных особенностей «доглобальной» эпохи, поскольку дискретность регионов утрачена навсегда - каждый регион связан с другими и вынужден сохранять эти связи в силу экономических причин.

Глокализация лингвистического ландшафта предполагает возврат к языковым традициям. Нация, этнос и социум существуют благодаря коллективной памяти, общей картине мира, совокупности знаний и мнений о действительности, зафиксированных в языке - наименованиях, прецедентных текстах, стереотипах. М. Бахтин в своей работе «К методологии гуманитарных наук» писал: «Текст живет, только соприкасаясь с другим текстом (контекстом). Только в точке этого контакта текстов вспыхивает свет, освещающий и назад и вперед, приобщающий данный текст к диалогу» (Bahtyn, 1979). Утрата или замена объектов коллективной памяти ведет к вымыванию ценностей социума, а затем - его исчезновению.

47

XLinguae Journal, Volume 8 Issue 2, April 2015, ISSN 1337-8384 
Глокализация лингвистического ландшафта г. Казани ярко вербализована в эргономиконе города, татарских вкраплениях в текстах слоганов и социальной рекламе. Этот процесс нашел отражение в письменных знаках коммерческой и социальной сфер, где особую популярность в последние годы обрели эргонимы, фиксирующие особенности Татарстана и г.Казани (Приволжанин, ДЮСШ, Приволжанка, ДЮСШ, Оргсинтез, бассейн, Мелита, двореи культуры, Басф Восток, ООО, торговая компания; Ак буре, ДЮСШ, Батыр, СДЮСШОР, Алтын Казан, магазин казанов в г. Казань, Исмал, магазин посуды), подтверждающие статус Казани как столицы Татарстана (Дом офицеров Казанского гарнизона, Шеморданский мясокомбинат, ОАО, представительство в г. Казани, Элитные семена Татарстана, ассоциация по nроизводству семян зерновых культур), а также отражающие картину мира местного населения (Жемчужина Вера, мусульманский дом, Куреш, федерация татаро-башкирской спортивной борьбы, Чингисхан, спорткомплекс, Райский уголок, оздоровительный комплекс).

Ученые выделяют четыре группы татарских эргонимов в г. Казани: 1) эргонимы, отражающие национальную культуру, являющиеся культурными кодами, символами: кафе Сөембикә, Биләр, Юргак, Өчпочмак, Кыстыбый, гостинииа и ресторан Болгар, спортивные комплексы Ак бүре, Тулпар, организации Болгар-Арыш Болгар-Медиа, Тулпар-сервис, аэроклуб Тулпар и др.; 2) эргонимы, отражающие религиозное мировоззрение мусульман: салоны-магазины женской одежды Айшә, Мөслимә, мужская парикмахерская Йосыф, названия продуктовых магазинов Хәләл ит, Хәләл ризык, Хәләл азык-төлек, кафе Хәләл, Әл-кәүсәр, Фирдәвес, Зәм-зәм, медицинский иентр Йасин, религиозные фонды Зәкать, Корбан; гостиница и иеентр оказания психологической помощи женщинам Фатыйма, учебно-образовательный цееттр Рәшидә, исламская средняя школа Госмания, мечети Фарук, Ризван и др.; 3) эргонимы, связанные с Востоком и отражающие культурные контакты с восточными странами, содержащие информацию о собственнике предприятия. Большинство эргонимов данной группы образованы от антропонимов, например: торговый комплекс Нагмир, агентство недвижимости Әль-Сәид, строительно-проектная организация Мостаф и др (Амирова, 2011). В последние годы особо популярны стали образы тюрко-татарской мифологии: Ак бүре (татар. Бельй волк), крылатый конь Тулпар, сказочный крылатый змей Зилант, леший Шурале, а также имена исторических героев: автомойка Чынгызхан (монгольский император), охранное предприятие Тамерлан (полководец, разгромивший Золотую Орду), кафе Сөембикә (татарская княжна) и др. В Казани названия компаний, производящих или продающих специфичные для Татарстана продукты питания или услуги, как правило, содержат татарские лексемы: кафе Катык (кисломолочный напиток), сеть супермаркетов Бәхэтле (тат. счастливый, удачливый), кафе Рәйхан (mam. базилик, базиликовый), Каймак (тат. сметана), Чак-чак (восточная сладость), Созвездие Йолдызлык, Айбят, досуговый центр Кояш (тат. солнце), Сабантуй (весенний татарский праздник), Майрам.

В настоящее время в Татарстане не только местные, но и мировые бренды привлекают широкий спектр языковых средств, традиционно обращаясь к лексикону татарского языка: Яна ел Билайн (mam. C новым годом) Кафе “Кыстыбый” вместе с известным брендом “Coca-Cola” разработали рекламный щит, вывеску “Cоса-Cola + Кыстыбый. Бергә тәмлерәк!» (тат. Вместе вкуснее). Сеть магазинов автозапчастей “Би-би” в своих аншлагах используют слоганы “Нам по пути!”, “Безгә бер юлдан!". В качестве татарских вкраплений используются высокочастотные лексемы, известные всем живущим в 
Татарстане, или лексемы, значение которых легко понимаемые по контексту. Например, торговая сеть Media Market активно использовала татарские вкрапления в своих рекламных акциях: Прогресс в каждый йорт (тат. дом), Инноваций күбрәк (тат. больше) в два раза. Высокие технологии за маленькие акча (тат. деньги). Әйбет (тат. хорошая) экономия на каждом гаджете.

Благодаря победе казанской футбольной команды «Рубин» широкую известность приобрел слоган Без булдырабыз! (mam. Mbl можем!), введённый в оборот президентом республики Минтемиром Шаймиевым: «Bnервые в истории республики благодаря игре нашего славного «Рубина» у нас есть чемпионы России по футболу! - воскликнул Минтимер Шаймиев. ...И «Рубин» будет состязаться с лучшими командами Европь. Без булдырабыз - мы можем!» [Советский спорт, 02 ноября 2008]. После победы «Рубина» в чемпионате России по футболу в Казани появились новые баннеры с надписью Без булдырдык! (тат. Мы смогли!).

Более 1000 рекламных щитов в городе занято под двуязычные проекты социальной рекламы, инициированные исполкомом столицы республики. Темы социальной рекламы в лингвистическом ландшафте г. Казани довольно традиционны: здоровый образ жизни (и профилактика СПИДа), соблюдение правил дорожного движения, призыв к исполнению гражданских обязанностей (уплата налогов, служба в армии и т.п.), бережное отношения к природе, воспитание патриотизма и любви к родине, семейные отношения (в том числе, повышение рождаемости), воспитание гуманизма и чувства ответственности за судьбу социально незащищенных людей. Например, Награда тебе будет больше, когда ты будешь делать должное, не надеясь на награду, Данное нами к нам же вернется, Душе израненной доброе слово - лекарство. Приводятся и цитаты из Корана: Творите благое, чтобы вы преуспели, Не следуй за тем, о чем у тебя нет знания, Помогайте друг другу в том, что касается благочестия, Делайте добро сиротам и таким, которые в нужде и другие.

\section{Лингвистический ландшафт г. Казани: количественный анализ}

Объем и плотность представленности языка в лингвистическом ландшафте суть косвенные параметры значимости языка в определенном социуме. Изучаемый языковой материал эргономикона г. Казани продемонстрировал следующее: 234 городского объекта именованы на русском языке (Дом книги, Дом чая, Цвета музыки, Глория, Серебро России, Приём платежей и др.), 177 знаков имеют в составе эргонима текст на иностранном языке (Mango, Incity, Cafe Junker, Jewellery fashion, Colin's, Samsung, Golden Kazan, Meat House, Media Star и др.), 67 эргонимов содержат только единицы татарского языка (Чәй йорты, Ашханә, Нур и др.). Единичны эргонимы на русском и татарском языках с иностранными вкраплениями ( Интеллект бар IQ, Татар Инн).

Однако географическая классификация рекламных текстов свидетельствует о доминирующем положении наименований, содержащих иноязычные элементы в центре города (см. Схема 1), в то время как наружная реклама периферийных улиц содержит преимущественно единицы русского происхождения. Татарский язык во всех случаях занимает третью позицию. 
Схема 1 Объем текстов наружной рекламы на русском, татарском и иностранных языках на ул. Баумана (центр г. Казани) и ул. Кулахметова, ул. Фучика (жилые микрорайоны г. Казани)

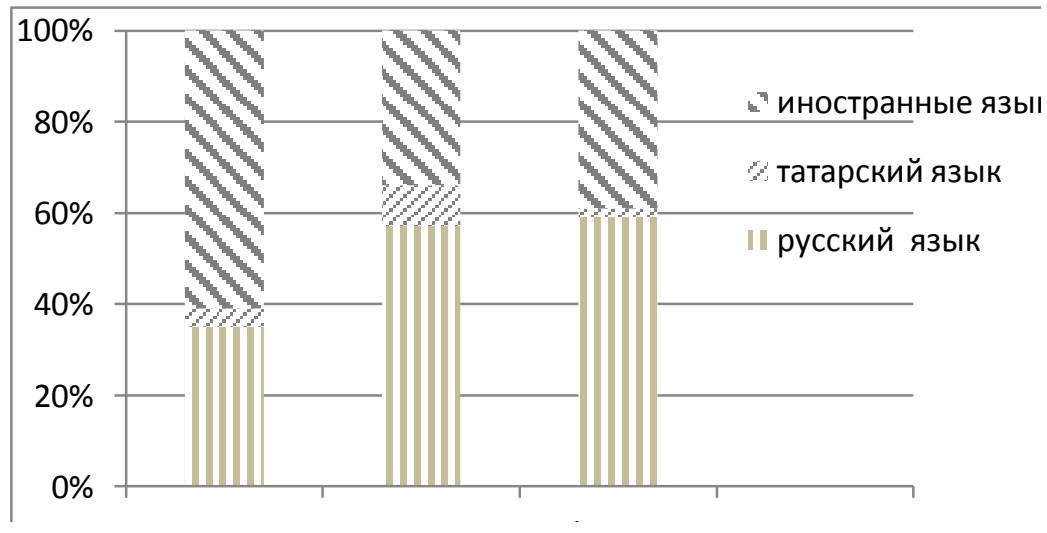

Заключение

Основные параметры современного лингвистического ландшафта г. Казани - вестернизация и глокализация - объективированы в поликодовости и трансформации традиционных аксиологических стереотипов русского и татарского этносов.

Изучаемый языковой материал эргономикона г. Казани продемонстрировал преимущественное положение русского языка, на втором месте по представленности находятся тексты на латинице (английский, немецкий, французский, испанский, итальянский и др.), третье место занимает татарский язык. Языковая поликодовость как основной параметр современного рекламного слогана г. Казани реализуется в нескольких вариантах (по объему представленности): западноязычное вкрапление в русском тексте, татарское вкрапление в русском тексте, русское вкрапление в татарском тексте, западноязыч ное вкрапления в татарском тексте. Монокодовость общественных знаков в лингвистическом ландшафте г. Казани нетипична.

Этнокультурная идентичность, объективируемая в объектах языкового ландшафта, является решающим условием связи языковой личности горожанина с историей и культурой этноса, страны, нации. Стремясь приобщиться к западной цивилизации и ее стандартам консьюмеризации, не гасим ли мы свет, приобщающий нас к диалогу с нашей историей?

\section{References}

AMIROVA, R.M. 2011. Tatarskaya ergonimiya goroda Kazany: avtoreferat dissertatsii kandidata philologicheskyh nauk. Kazan.

ASTAFYEAVA , I.A. 1996.Sposoby nominatsii v rechevoy situatsii goroda (na materiale oykodomonimov goroda Omska): dissertatsiya kandidata philologicheskyh nauk. Moskva.

AVDOKUSHYN, E.F. 2009. «Novaya economica» y economicheskiy krizys. In: Voprosy novoy economiky. Vyatckiy sotsial'no-economicheskiy institut. ISSN 19940556

BACKHAUS, 2007. Linguistic Landscape. A comparative Study of Urban Multilingualism in Tokio. In: Multilingual Matters. NY- Ontario - Clevalon.

BAHTYN, M.M. 1979.K metodologii gumanytarnyh nauk. Moskva.: Iskusstvo. 
BESPALOVA, A.V. 1984. Strukturno - semanticheskie modely ergonimov y ih upotreblenie $\mathrm{v}$ sovremennom angliyskom yazike (na materiale nazvaniy firm, kooperativov, i t.d.): dissertatsiya kandidata philologicheskyh nauk. Odessa.

BESPALOVA, A.V. 1991. Printsipy y sposoby nominatsii v angliyskoy ergonimii (na materiale nazvaniy firm y companiy). Nominatsia v onomastike. Sverdlovsk: Isdatel'stvo UrGU, pp. 158-167.

DROBIDZEVA, L. M. 2003. Sotsialniye problemy mezhnatsionalnyh otnosheniy v postsovetskoy Rossii. M. Tsentr obshechelovecheskyh tsennostey. ISBN 5-88790064-4

DYAKOV, A.I. 2003. Prichiny intensivnogo zaimstvovaniya anglitsizmov v sovremennom russkom yazike. In: Yazyk y cultura. Novosibirsk: Izd -vo NGU, pp. 35-43.

EMELYANOVA, A.M. 2007. Ergonimy v lingvisticheskom landshafte polyetnicheskogo goroda (na primere nazvaniy delovyh, commercheskyh, culturnyh, sportyvnyh ob'ektov goroda Ufy): dissertatsiya candidata philologicheskyh nauk. Ufa, $170 \mathrm{p}$.

FRISBY, D. 2002. The metropolis as text. Otto Wagner and Vienna's «Second Renaissance». London: Routledge.

GALIULLIN, K.R.1998. Sovremennie yazikovie contakty na territorii Tatarstana: tatarizmy v russkoy rechy. In: Problemy leksikologii y leksikografii tatarskogo yazika. V. 3. Kazan: Fiker, pp. 108-114. ISBN 5-201-08039-1

GALIULLINA, G.R.- BADRETDINOV, R.B. 2008. Funktsionirovanie antroponimov $\mathrm{v}$ kachestve ergonimov $\mathrm{v}$ tatarskom lingvokulturnom prostranstve. Kazan: Izd-vo Kazan. un-ta, pp. 95-99.

GARIPOV, Y.Z. - SOLNYSHKINA, M.I., 2006. Language Reforms in the Tatarstan Education System and Ethnolinguistic Orientation of the Youth. Dublin. Ireland.

GARIPOV, Y.Z. 2002. Tendentsii razvitiya natsional'nogo yazika. In: Sotsiologicheskiye issledovaniya, pp. 3-13.

GASPAROV, B.M 1996. Yazyk, pamyat', obraz. Lingvistika yazikovogo suchestvovaniya. Moskva: Novoe literaturnoe obozreniye. ISBN 5-86793-020-3

GORODOV, O.A. 2006. Pravo na sredstva individualizatsii: tovarniye zhaky, znaky obsluzhivaniya, naimenovaniya mest proishozhdeniya tovarov, firmenniye naimenovaniya, commercheskiye oboznacheniya "Wolters Kluver", [online] <http://www.lawmix.ru/commlaw/1295>.

GOSUDARSTVENNAYA programma Respubliky Tatarstan po sohraneniyu, izucheniyu y razvitiyu gosudarstvennyh yazykov Respubliky Tatarstan y drugih yazyjiv v Respublike Tatarstan na 2004 - 2013 gody. 2004. Kazan.

HISAMOV, O.R. 2010. Kazan shahare tatarcha elma taktalardagy hatalar turynda. Kazan: Ihlas nashr, pp. 250-253.

ILYUHINA, N.A. 1999. Obraz kak ob'ekt y model semasiologicheskogo analyza: dissertatsiya doctora philologicheskyh nauk. Ufa.

ISAEVA, M.G. 2010. Strukturnye tipy kodovyh pereklyuchenii v pis'mennyh tekstah SMI. In: Chetvertaya mezhdunarodnaya konferenciya po kognitivnoi nauke: Tezisy dokladov. T. 2. Tomsk, pp. 301-303.

KARABULATOVA, I.S. 2013. The Problems of Linguistic Modeling of New Eurasian Linguistic Personality in Multilinguistic and Mental Environment (By Example of Onomasphere). In: Middle-East Journal of Scientific Research, pp. 791795. ISSN 1990-9233

KARABULATOVA, I.S. 2013. Turkic and Slavs: Bi-Polylinguism in Globalization and Migrations (On an Example of Tumen Region). In: Middle-East Journal of Scientific Research, pp. 832-836. ISSN 1990-9233

MAFFI, L. 2003. Ugroza yazyku - ugroza znaniyu. In: Mezhdunarodnyi zhurnal social'nyh nauk, pp. 119-128. ISSN 0869-4281 
MOL', A. 2008. Sotsiodinamoka kultury. Moskva: Izd-vo LKI. ISBN 978-5-38200433-4

NIZAMOV, I.M. 2006. Tatar sotsiolingvistikasy. Kazan: Kazan universitety nashriyate, ISBN 5-98180-234-0

NIZAMOV, I.M. 2008. Yardamen belyan synen. Kazan: Magarig. ISBN 978-5-77611823-4

OSNOVNIE itogi vserossiyskoy perepisy naseleniya. 2003. Moskva: Goscomstat Rossii.

PENNYCOOK, A. 1994. The cultural politics of English as an international language. London: Longman.

PHILLIPSON, R. 2003. English-only Europe? Challenging Language Policy. London: Routledge.

RIVLINA, A. A. 2010. O yavlenii "glokalizatsiya" v semanticheskom razvitii angloyazychnyh zaimstvovaniy. Moskva: Tsentr po izucheniyu vzaimodeystviya cultur FIY MGU im. M.V. Lomonosova, pp. 299-308

ROBERTSON, R. 1992. Globalization:social theory and Global Culture. London.Thousand Oaks: Sage Publications.

SHELESTYUK, E. V. 2012. Angloyazichnaya lingvokul'ternaya expansiya. In: Yazik y literatura $\mathrm{v}$ nauchnom dialoge: aktual'niye voprosy sovremennoy philologii. Izhevsk; Granada. V. 2, pp.224-250.

SHELESTYUK, E.V. 2012. Lingvokul'turniy aspect yazikovoy politiky. In: Vestnik Chelyabinskogo gosudarstvennogo universiteta. № 36 (290). Philologiya. Iskusstvovedenir. V. 72, pp. 72-81.

SHOHAMY, E. - GORTER, D. 2009. Linguistic Landscape: Expanding the scenery. New York: Routledge.

SHTEPA, V. 2004. RUTopiya [online] <http://www.ozon.ru/context/detail/id/2340734/>. SHVEYTCER, A.D. - NICOL'SKIY, L.B. 1978. Vvedenie v sotsiolingvistiku: dlya institutov y fakul'tetov inostrannyh yazikov. Moskva: Vysh. shkola.

SMOLYAKOVA, L.P. 1982. Nekotorie turkskie zaimstvovaniya v leksike pichy v russkyh govorah zapadnyh rayonov Tatarii. Vzaimovliyaniye y vzaimoobogasheniye narodov SSSR (po materialam avtonomnyh respublik Povolzhya y Priuralya). Kazan, pp. $74-81$.

SOLNYSHKINA, M.I. - GARIPOV, Y.Z. 2003. Language policy in national Republics of Russia: ideology and practice of Tatarstan. Southampton. [online] $<$ http://www.lang.soton.ac.uk/lipp/abstracts.html>.

SOTSIOLINGVISTICHESKIE problemy funktcionirovaniya gosudarstvennyh yazikov Respubliky Tatarstan. 2007. Kazan: Tat. knizhnoe izd-vo, pp. 20. ISBN 9785-298-01569-1

SYSTEMA standartov ergonomiky y tehnicheskoy estetiky. 1984. [online] <http://www.complexdoc.ru/text/ГОСТ30.001-83/1>.

TANNER, T. 1992. Venice Desired. Harvard: Harvard University Press, pp. 366-368. YAZYK y soznaniye: paradoksal'naya racional'nost'. 1993. Moskva: Izd-vo IY RAN. TUROMA, S. 2009. Semiotika gorodskogo prostranstva Y.M. Lotmana: opyt pereosmysleniya. Novoe literaturnoe obozrenie.

\section{Resources}

AHMADIEV, F.G. 2001. Naimenovaniya ulits goroda Kazany: spravochnyk. GOSUDARSTVENNIYE yaziky v tekstah vyvesok. 2012. [online] <http://www.kzn. ru/old/page18016.htm>.

SOVETSKY sport. 02. 11. 2008. [online] <http://www.sovsport.ru/news/text-item/ 310104_12>. 
UPRAVLENIYE arhitectury y gradostroitel'stva ispolnitel'nogo komiteta g. Kazani. [online] <www.uag.kzn.ru>

ZAKON Respubliky Tatarstan «O gosudarstvennyh yazikah Respubliky Tatarstan y drugyh yazikah v Respublike Tatarstan» (v red. Zakona RT ot 28.07.2004 N 44-3RT).

[online] <kros.ru/_educ/zrt-gosyaz.doc >.

Words: 6625

Characters: 55195 (30,66 standard pages)

Prof. Marina Ivanovna Solnyshkina, DrSc.

Department of Contrastive Linguistics and Linguodidactics

Institute of Philology and Intercultural Communication

Kazan (Volga) federal university

Kremlovskaya 18

420008 Kazan

Russia

mesoln@yandex.ru

Aliya Rinatovna Ismagilova

English language department

Institute of Language

Kazan (Volga) federal university

Kremlovskaya 18

420008 Kazan

Russia

ismalisha@mail.ru 